\title{
Connecting Eurasia and the Americas: Geopolitical Implications of the Bering Strait Crossing in the Age of Globalization
}

\author{
Asst. Prof. Dr. Çağrı Erdem (Doğuş University, Turkey)
}

\begin{abstract}
The Bering Strait crossing would link the entirety of Eurasia to the entirety of the Americas. There are some immense geopolitical benefits of such project. It would bring about a deep and lasting change to global economic outlook. A possible tunnel under the Bering Strait and extension of the railroad network could open vast areas of Siberia containing mineral deposits necessary for global economic growth. According to a number of respectable Russian geologists, Siberia/the Arctic region is home to considerable amount of minerals and fossil fuels. The most valued function of the Bering Strait rail system would be to release those vast natural resources trapped underneath the tundra and permafrost for the benefit of Russia and the world. These resources can be used for global economic development. Moreover, the rail project would also build development corridors in the underdeveloped parts of Russian Siberia. The development of those resources in question and their rapid transportation to the global markets can contribute to overall development of Siberia. This paper will explore/evaluate the possible benefits of the Bering Strait crossing from Russian perspective and Russia's new role in the Arctic region, under the frame of geopolitics.
\end{abstract}

\section{Introduction}

Since the end of the Cold War and the beginning of the $21^{\text {st }}$ century, rivalries between the great powers over natural resources have become astonishingly intense. This competition has reaffirmed itself in rapid growth of commodity prices and some adjustments in geopolitical considerations. Russia has been benefiting from this situation due to its abundant natural resources on its vast territory.

The rich history of Russian political and economic relations gives ample of leadership examples. The avantgarde pushes the boundaries of what is accepted as the norm or the status quo in various issue areas. That Russian peculiarity creates many opportunities to determine Russia's place in the world. This history, in many respects, provides also commanding clues vis-à-vis Russia's current position in global political economy. Furthermore, the Bering Strait crossing project, although it seems for many as a misapprehension, reflects that Russian avant-garde drive and spirit.

The Bering Strait rail system by letting loose those vast natural resources trapped underneath the tundra and permafrost would facilitate the development of those resources in question and their rapid transportation to the global markets can contribute to overall development of those regions. There is no doubt that those rail connections in the Russian Far East (RFE) would also generate a development corridors within which new urban centers would flourish and existing ones would gain further dynamism-having an impact similar to the construction of Trans-Siberian Railroad in the early $20^{\text {th }}$ century.

Right now, most of Siberian population is concentrated around Trans-Siberian railroad and the RFE is practically empty. As new cities erupt or the existing ones enlarge, they will magnify the erection of brand-new manufacturing businesses/assembly lines, and necessitate the construction of school systems, electricity grids, water systems, health/hospital systems; this will indubitably entail an expansion of the labor force and overall population, which in turn would increase the population density in those thinly populated areas. Equally, it would be fair to assume that, on geopolitical level, the movement of goods between Eurasia and the Americas, at previously unheard-of speeds, would revolutionize global productive connections (Deniston, 2013; Douglas, 2007; Nikishenkov, 2011; Panin, 2013).

\section{Increased Significance of Natural Resources for Global Economic Development}

It is central to emphasize the relevance of natural resources regarding the Bering Strait crossing project. Natural resources, certainly, are a source of potential international cooperation. The shared interest of producers and consumers in commodity trade can be the source of harmonious relations among states. International cooperation is needed to bring those resources from remote reserves to consumer centers. To this end, development projects such as the Bering Strait crossing can be structured in a way that all the participants would benefit from them (Moran \& Russell, 2009; Ross, 2004; Russett, 1979; Stulberg, 2007; Victor \& Victor, 2003; Winchester; Winrow, 2007; Yergin, 2006).

On the other hand, a competition for natural resources - necessary for any economic development — can also be a source of potential conflict between states. For instance, energy resources are regarded as a source of zerosum or mixed-sum competition because the amount of hydrocarbons in the world is limited (Chun, 2008; Ebel, 2009). To a great extent, politics determines economics and reflects the concern for war. The view that force and the threat to use force are the salient features of the international system means that states must prepare for future 
conflicts. Heavy reliance on foreign suppliers for strategic resources, such as oil, natural gas and coal, can be a threat to national security. Consequently, in a situation of a crisis or a war, access to those vital resources can be denied. Given the importance of energy to a state's ability to wage war, disruptions in supply could put national security and independence at risk.

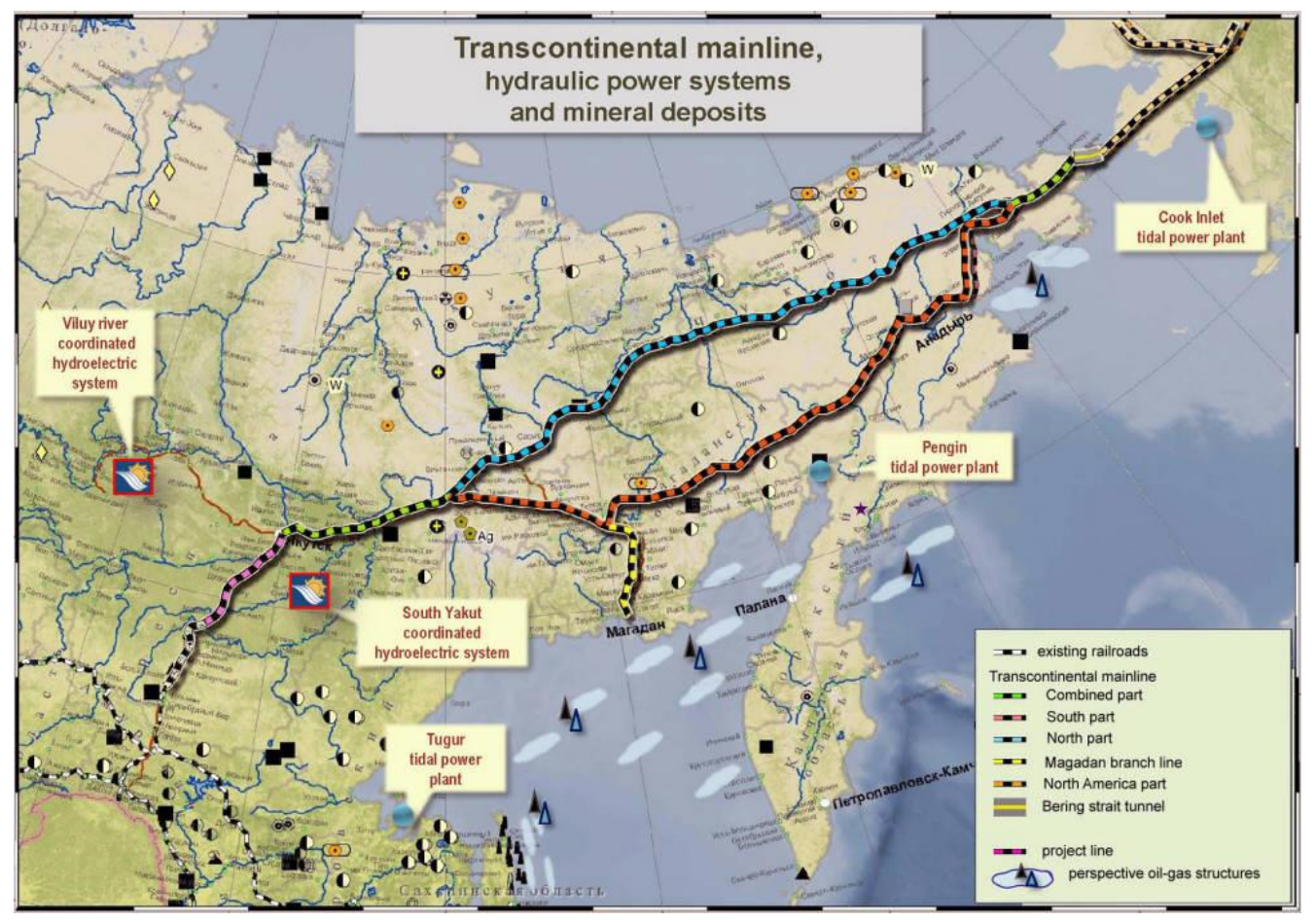

Figure 1: Transcontinental Mainline, Hydraulic Power Systems and Mineral Deposits (Razbegin, 2011)

In that aspect, the Siberia and Russian Arctic Region has been of particular interest to the great powers due to its possibly vast natural resources and strategic location. In fact, any sort of analysis of energy issues can no longer be reduced merely to a discussion of supply and demand in the world market, but must also focus on global energy security, from geopolitical and geoeconomic perspectives. In this milieu, major oil and gas consumers such as the United States, European Union, China, Japan, South Korea and India are paying close attention to the developments in that particular region. To this end, Russia is making every effort to retain influence over its own strategic resources (Howard, 2009).

It is critical to understand that Siberia (Akaha, 1997; Davis, 2003; Forsyth, 1992; Gentes, 2008; Groisman \& Gutman, 2013; Hill \& Gaddy, 2003; Hudgins, 2003; Jordan \& Jordan-Bychkov; Naumov, 2006; Wood, 2011) and Russian Arctic are one of the richest regions in the world in terms of its petroleum, natural gas, coal and mineral resources. It also has immense geopolitical importance. Over the last two decades, there has been considerable interest vis-à-vis the Arctic region in Western academic circles (Allain, 2011; Anderson, 2009; Byers, 2009; Emmerson, 2010; Erdem, 2013; Gerhardt, Steinberg, Tasch, Fabiano, \& Shields, 2010; Grant, 2010; Howard, 2009; Wilder, 2010; Young, 2011) and in Russian academia (Evdekimov, Vsotskaya, \& Kostlev, 2012; Ivashov \& Kefeli, 2012; Kharlampieva, 2011; Konovalov, 2010; Kozmenko, Selin, \& Shchegolkova, 2012; Kuznetsov, 2011; Lebedev, 2011; Nikolaeva, 2010; Rudomiotkin \& Nagorskiy, 2010; Savelyeva \& Shiyan, 2010; Selin \& Tsukertan, 2008; Sosnin \& Ryzhov, 2010; Stolbov, 2009; Tamitskiy, 2012; Timoshenko, 2011; Vasilev, Selin, \& Tereshchenko, 2009; Vsevolodovich, 2012).

With the advances in science and technology (particularly over the last decades), it is possible to measure and quantify the economic potential of those resources more accurately. Consequently, it would be fair to argue that this changing situation made the region more attractive for big powers surrounding it. Russia, with an extensive coastline in the Arctic zone, increased its strategic operations and started to sign some international economic agreements concerning the region (Byers, 2009; Dalby, 2003; Emmerson, 2010; Fairhall, 2010; Gerhardt et al., 2010; Grant, 2010).

\section{Significance of the Bering Strait Crossing for Siberia and the RFE}

Since the beginning of the 20th century, Russia and the United States have been holding talks on probable collaboration on this issue and gave some eminent indications of joint efforts to construct a railway tunnel under the Bering Strait to link Siberia with Alaska. During the Asia-Pacific Economic Cooperation (APEC) Forum in 2012 at Russian Pacific port city of Vladivostok, Russian Railways President asserted the fact that the project 
to extend a railway line to Kamchatka and then to build a tunnel across the Bering Strait could be actualized in not a very distant future. (Douglas, 2007) The technical and financial aspects of the project is not that much related to the tunnel itself (somewhere around 100 kilometers), but in building links to the tunnel from existing rail lines in Russia, the United States and Canada. On the one hand, from Russian perspective, the Bering tunnel is meant to subsequently connect to the Trans-Siberian and Baikal-Amur Mainline-Байкало-Амурская магистраль - БАМ / Baikalo-Amurskaya magistral - and would require about 4,000 kilometers of rail lines to be built from Yakutsk (Sakha Republic/Yakutia). On the other hand, in the United States and Canada, approximately 2,000 kilometers of track would need to be made ready from the tunnel's landing point to the existing rail connection in Canada. It is difficult to come up with exact figures on the total cost of the project. However, estimates ranges from \$35 billion to as much as \$100 billion (Panin, 2013).

Moreover, Russia plans to build also a railroad that links Eurasia with Sakhalin Island-extremely well endowed in terms of natural gas fields — and eventually reaching Japan's northern island of Hokkaido. The Ministry for Development of Russian Far East said that construction will start in 2016 on the 580-kilometer railroad that will connect the Khabarovsk region and Sakhalin Island. A bridge is envisioned over the narrowest part of the Tatar Strait. The entirety of the project is estimated to be at around \$10 billion (Nishimura, 2013).

In recent years, the Russian Far East (RFE) has also been a point of interest in academic circles (Alexeeva, 2008; Arsenov, Artemkina, \& Zaboev, 2005; Barkovsky, 2006; Blank, 2011; Bliakher \& Vasil'Eva, 2010; Kangas, 2007; Kuhrt, 2012; Nemchaninova \& Buldygerova, 2012; Rozman, 2008; Sullivan \& Renz, 2010; Troyakova, 2007; Vishinevskii \& Demyanenko, 2010; Zausaev, 2012). It is considered as a region in crisis due to troubled economic conditions, corrupt governance, and problem-ridden cross-border relations with China, Japan, and both Koreas (Rozman, 2008). Due to the some fears that the Russian Far East might disengage itself from the center and other regional/global powers may end up having a major grip in the region, Moscow started to show some genuine interest in those eastern border provinces (Kangas, 2007).

The region in question covers a large geographical area from Siberia to Russia's Pacific coast, forming the northeastern corner of Asia. Although the Far East constitutes one-third of Russia's total landmass, it has only 6.6 million residents -4.7 percent of the total population. The low population density, just over one person per square kilometer, makes the region one of the most sparsely populated places in the world. The scarcity of residents exists alongside a wealth of natural resources that have attracted the interest of the Russian central government as well as foreign investors. Evidently, Russian politicians, bureaucrats/technocrats are all concerned about the level of socioeconomic development in that region (Troyakova, 2007).

However, it would be fair to assert that the developmental troubles of the RFE partly related to the region's history and location. The USSR did also neglect socio-economically the region until its collapse in 1991. After the disintegration of the Union, the RFE, like many other regions, was to a great extent abandoned by the financially struggling central government in Moscow. The extended negligence towards the region has left the RFE provinces economically vulnerable, demographically challenged, and geographically exposed. However, Russian government has recently begun to focus unequivocally on rejuvenating the RFE, as years of dynamic economic growth and surging global trade in neighboring China have pulled the international community's recognition to developments in the Pacific region. This transformation in the international political and economic state of affairs, particularly in view of the region's rich supplies of natural resources and strategic location, has brought about a reassessment of Moscow's policy in Russia’s Far East (Alexeeva, 2008; Blank, 2011).

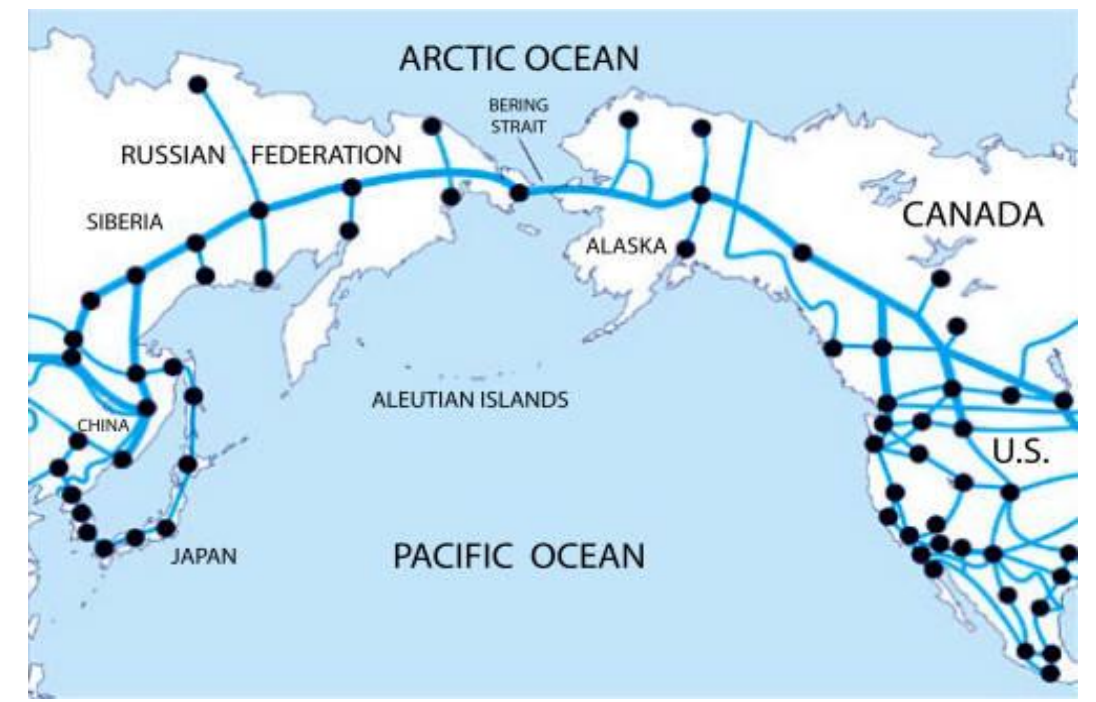

Figure 2: Interhemispheric Railroad \& Bering Strait Tunnel Maps and Projects Future New Railroads (InterBering, 2013) 
Russian leadership considers the development of transportation infrastructure as fundamental element for uplifting those gargantuan underdeveloped regions of Siberia and the RFE. According to some experts the planned road, rail, and pipeline system would handle 3\% of total global trade. Moreover, it will make it possible to connect more of eastern Russia's hydroelectric potentiality-Russian leadership envisions a 4,000-km rail line from the Lena River to the Bering Strait, as a high-priority task and very consequential. The Lena is the easternmost of Siberia's three great river systems (others being Yenisei and Ob Rivers), and is the tenth longest river in the world. Consequently, it will allow development of previously inaccessible mineral resource deposits. The connection of the power systems of Siberia, the RFE, and North America will generate considerable economies in electricity supply (Douglas, 2007).

There is no doubt that a spectacular economic growth is taking place in Asia and the world's economic center swings towards the Pacific region. The prevalence of transatlantic trade is losing momentum to the benefit of transpacific trade. Industrial regions of China, South Korea, and Japan can be linked up to Russian railroad system with the ultimate goal of connecting them to the manufacturing centers of the Midwestern United States and the critical Pacific ports in California, Washington State and British Columbia (see Figure 2). The Bering Strait crossing can be a critical raison d'être to trigger such project. Consequently, it is possible to observe a major geopolitical shift towards the Pacific region. By the same token, due to global warming, the melting of Arctic ice is opening up northern shipping routes and the Arctic development is increasingly becoming an area of significance with major untapped resource deposits. The extensive resources available in the Arctic can be developed and raw/semi-processed/processed goods can be rapidly delivered to the industrial centers in question at each end of Asia and North America, radiating the effects of a higher level of productivity throughout the global economy (Deniston, 2013).

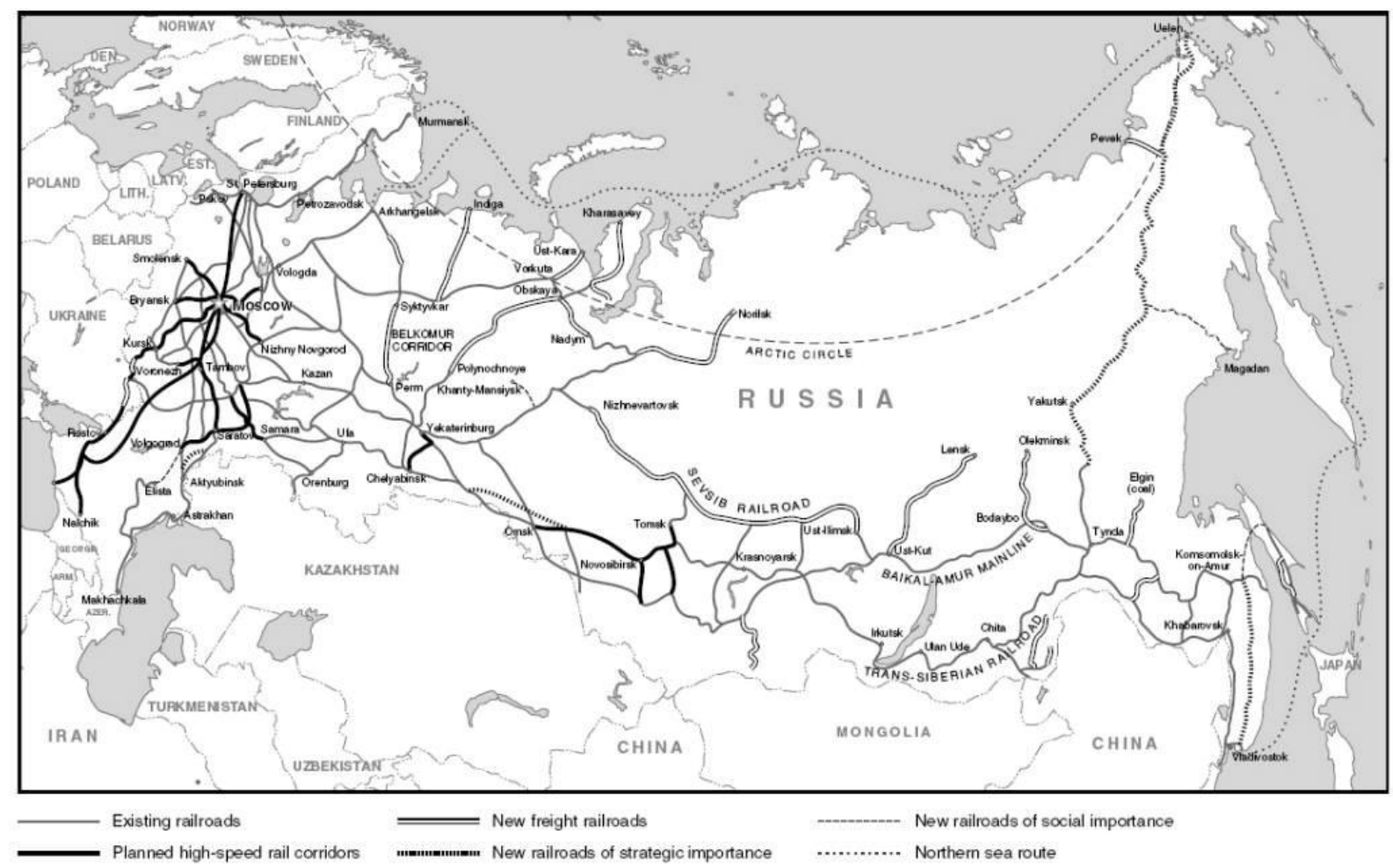

Figure 3: Russian Railroad Development to 2030 (Razbegin, 2007)

\section{Conclusion}

Along the same line of logic, the current project of connecting Eurasia with the Americas has a great potential. It would be unfair to depict the conceptual framework of this project just as a railroad tunnel. This is about the construction of a major transport route connecting four continents which would include high-speed electric trains, a highway, power lines, oil and gas pipelines, fiber optics and other infrastructure. Opposing arguments, mainly from some economists, indicate serious concerns and doubts about the economic feasibility of the project. It would be important to remember that at the Turn of the Century, on macroeconomic level, some economists/experts claimed that the Trans-Siberian Railroad-Tранссибирская магистраль/Transsibirskaya Magistra built between 1891 and 1916 - would also not pay for itself, but it did so in only six years. More importantly, this visionary project, politically and militarily made the Tsarist Russia a powerful player in any Eurasian geostrategic calculations. Equally, the current project would also take a number of years to complete 
but would pay for itself considerably fast. It could contribute tremendously to Russian political/economic power in Eurasia.

Moreover, the Bering Strait crossing has a wider significance for global politics, security and economics due to the fact that the adjacent states with almost 30 million $\mathrm{km}^{2}$ forms one fifth of earth's landmass and one third of global GDP. Russia and The United States are two of the most prominent states of the international system as permanent members of the UN Security Council.

\section{References}

- Akaha, T. (Ed.). (1997). Politics and Economics in the Russian Far East: Changing ties with Asia-Pacific London: Routledge.

- Alexeeva, O. (2008). Chinese Migration in the Russian Far East. [Article]. China Perspectives, 2008(3), 2032.

- Allain, M. A. (2011). Canada's Claim to the Arctic: A Study in Overlapping Claims to the Outer Continental Shelf. Journal of Maritime Law \& Commerce, 42(1), 1-47.

- Anderson, A. (2009). After the Ice: Life, death, and Geopolitics in the New Arctic. New York: Smithsonian Books.

- Arsenov, V. I., Artemkina, E. V., \& Zaboev, A. I. (2005). Rossiya v sisteme mejdunarodnih evroaziatiskih transportnih koridorov: sovremennoy sostoyanie, problemi, perspektivi i konkurentosposobnost. Rossiskiy Vneshneekonomicheskiy Vestnik (1).

- Barkovsky, A. N. (2006). Obrechen li Rossisky Dalny Vostok na sudbu tranzitnoy territoriy? Rossiskiy Vneshneekonomicheskiy Vestnik (3).

- Blank, S. (2011). Russia's Geo-economic Future; The Security Implications of Russia's Political and Economic Structure. [Article]. Journal of Slavic Military Studies, 24(3), 351-395.

- Bliakher, L. E., \& Vasil'Eva, L. A. (2010). The Russian Far East in a State of Suspension. [Article]. Russian Politics \& Law, 48(1), 80-95.

- Byers, M. (2009). Who owns the Arctic? Understanding sovereignty disputes in the North. Vancouver: Douglas and McIntyre.

- Chun, H. (2008). Russia's energy diplomacy toward Europe and Northeast Asia: a comparative study. Asia Europe Journal, 7(2), 327-343. doi: 10.1007/s10308-008-0206-y

- Dalby, S. (2003). Geopolitical Identities: Arctic Ecology and Global Consumption. Geopolitics, 8(1), 181 202. doi: $10.1080 / 714001009$

- Davis, S. (2003). The Russian Far East: The Last Frontier Postcommunist States and Nations. London: Routledge.

- Deniston, B. (2013). The Pacific Development Corridor: Maglev Across the Bering Strait. Executive Intelligence Review, 40(36).

- Douglas, R. (2007). Russian-American Team: World Needs Bering Strait Tunnel! . Executive Intelligence Review, 34.

- Ebel, R. E. (2009). The Geopolitics of Russian Energy: Looking Back, Looking Forward. Washington, DC: Center for Strategic \& International Studies.

- Emmerson, C. (2010). The Future History of the Arctic. London: The Bodley Head.

- Erdem, C. (2013). Challenging perspectives on security and environment in the Arctic: Russia vs the West. In S. Panarin \& D. Polyvyannyy (Eds.), Security in the West, in the East, and in Russia: Perceptions, Concepts, Situations-Безопасность на Западе, на Востоке и в России: представления, концеп-ции, ситуации (рp. 408). Ivanovo Ivanovo State University Publishers.

- Evdekimov, G., Vsotskaya, N., \& Kostlev, I. (2012). Osvoenie Arkticheskih Mestorozhdenii i Razvitie Sudokhodstva po Severnomu Morskomu Puti. Morskoy Sbornik, 1983(6).

- Fairhall, D. (2010). Cold front: conflict ahead in Arctic waters. New York: I. B. Tauris.

- Forsyth, J. (1992). A History of the Peoples of Siberia 1581-1990. Cambridge: Cambridge University Press.

- Gentes, A. A. (2008). Exile to Siberia, 1590-1822. New York: Palgrave Macmillan.

- Gerhardt, H., Steinberg, P. E., Tasch, J., Fabiano, S. J., \& Shields, R. (2010). Contested Sovereignty in a Changing Arctic. Annals of the Association of American Geographers, 100(4), 992-1002.

- Grant, S. D. (2010). Polar Imperative: A History of Arctic Sovereignty in North America. Vancouver: Douglas and McIntyre. 
- Groisman, P., \& Gutman, G. (Eds.). (2013). Regional Environmental Changes in Siberia and Their Global Consequences New York: Springer.

- Hill, F., \& Gaddy, C. G. (2003). The Siberian Curse: How Communist Planners left Russia out in the Cold Washington D.C.: Brookings Institutions Press.

- Howard, R. (2009). The Arctic Gold Rush: The New Race for Tomorrow's Natural Resources. London: Continuum.

- Hudgins, S. (2003). The Other Side of Russia: A Slice of Life in Siberia and the Russian Far East. College Station: Texas A\&M University Press.

- InterBering. (2013). Interhemispheric Railroad \& Bering Strait Tunnel Maps and Projects Retrieved April 02, 2014, from http://www.interbering.com/Bering-railroad-maps.html

- Ivashov, L., \& Kefeli, I. (2012). Morskaya Moshch' Rossiyskoy Arktiki: Geopoliticheskiy Aspekt. Morskoy Sbornik, 1983(6), 43-49.

- Jordan, B. B., \& Jordan-Bychkov, T. G. Siberian Village: Land and Life in the Sakha Republic Minneapolis: University of Minnesota Press.

- Kangas, R. (2007). The Changing Face of the Russian Far East: Cooperation and Resource Competition Between Japan, Korea, and China in Northeast Asia. Perspectives on Global Development \& Technology, 6(1-3), 441-460.

- $\quad$ Kharlampieva, N. K. (2011). Arktika - Novyi Region Mira. Izvestya saratovskogo Universiteta. Novaya Seriya. Seriya: Sotziologiya. Politologiya, 1, 97-101.

- Konovalov, A. (2010). Strategiya Razvitiya Arkticheskoy Zony Rossii. Morskoy Sbornik, 1961(8).

- Kozmenko, S., Selin, V., \& Shchegolkova, A. (2012). Geoekonomicheskie Vyzovy: Morskoy Politiki v Rossiyskoy Arktike. Morskoy Sbornik, 1983(6), 33-42.

- Kuhrt, N. (2012). The Russian Far East in Russia's Asia Policy: Dual Integration or Double Periphery? [Article]. Europe-Asia Studies, 64(3), 471-493.

- Kuznetsov, N. (2011). Pamyat' Rossiskoy Arktiki. Morskoy Sbornik, 1975(10), 39-43.

- Lebedev, G. (2011). Geopoliticheskie Interesy Rf b Arktike. Morskoy Sbornik, 1977(12), 27-32.

- Moran, D., \& Russell, J. A. (Eds.). (2009). Energy Security and Global Politics: The Militarization of Resource Management. New York: Routledge.

- Naumov, I. V. (2006). The History of Siberia. London: Routledge.

- Nemchaninova, M. A., \& Buldygerova, L. N. (2012). Concession as a Form of Attraction of Foreign Capital (on the Example of the Concession Policy in the Russian Far East in the 20ths of the XX century). (English). [Article]. Bulletin of PNU, 26(3), 203-210.

- Nikishenkov, O. (2011). Digging to America, The Moscow News.

- Nikolaeva, A. B. (2010). Gosudarstvennaya Ekonomicheskaya Politika v Mirovoy Arktike. Sever i rinok: formirovanie ekonomicheskogo poryadka, 1(25), 49a-53.

- Nishimura, D. (2013). Russian Far East railway project may extend to Hokkaido, Asahi Shimbun

- Panin, A. (2013). Trans-Siberian Railroad Getting New Lease on Life, The Moscow Times.

- Razbegin, V. N. (2007). Prospective Topology of the Russian Federation's Rail Network Development until 2030 Retrieved April 02, 2014, from http://www.interbering.com/Bering-railroad-maps.html

- Razbegin, V. N. (2011). Transcontinental Mainline, Hydraulic Power Systems \& Mineral Deposits Retrieved April 02, 2014, from http://www.interbering.com/Bering-railroad-maps.html

- $\quad$ Ross, M. L. (2004). How Do Natural Resources Influence Civil War? Evidence from Thirteen Cases. International Organization, 58(01). doi: 10.1017/s002081830458102x

- $\quad$ Rozman, G. (2008). Strategic Thinking About the Russian Far East: A Resurgent Russia Eyes Its Future in Northeast Asia. [Article]. Problems of Post-Communism, 55(1), 36-48.

- $\quad$ Rudomiotkin, A., \& Nagorskiy, A. (2010). Arktika kak Vazhneishee Napravlenie Rossiskoy Morskoy Deyatel'nosti. Morskoy Sbornik, 1961(8).

- $\quad$ Russett, B. (1979). World Energy demand and World Security. Policy Sciences, 11(2), 187-202.

- Savelyeva, S., \& Shiyan, G. (2010). Geopoliticheskie Predposylki Ekonomicheskogo Osvoeniya Arktiki. Morskoy Sbornik, 1955(2).

- Selin, V., \& Tsukertan, V. A. (2008). Rossiya i Mir v XXI Veke: Geopoliticheskie i ekonomicheskie faktory Obespechniya Suvereniteta Rossii v Arktike. Rossia i sovremenniy mir, 2, 76-84. 
- Sosnin, V., \& Ryzhov, G. (2010). Vosstanovlenie Kontrolya za Vozdushnoy i Nadvodnoy Obstanovkoy v Arktike - Vazhneishaya Zadacha Rossii. Morskoy Sbornik, 1960(7), 32-37.

- Stolbov, A. (2009). Arktika - Prioritetnoe Napravlenie Strategii Razvitiya Morskoy Deyatel'nosti. Sever i rinok: formirovanie ekonomicheskogo poryadka, 3(24), 19-23.

- Stulberg, A. N. (2007). Well-Oiled Diplomacy: Strategic manipulation and Russia's Energy Statecraft in Eurasia. Albany: State University of New York Press.

- Sullivan, J., \& Renz, B. (2010). Chinese migration: still the major focus of Russian Far East/Chinese North East relations? [Article]. Pacific Review, 23(2), 261-285.

- Tamitskiy, A. (2012). Gosudarstvennaya Politika Sovremennoy Rossiy v Arktike: Etap, Prioritety i Nekotorye Itogi. Arktika i Sever, 6.

- Timoshenko, A. (2011). Rossiskaya Regional'naya Politika v Arktike v XX-XXI bb.: Problemy Strategicheskoy Preemstvennosti. Arktika i Sever, 4.

- Troyakova, T. (2007). The Russian Far East: Isolation or Integration? Problems of Post-Communism, 54(2), 61-71.

- Vasilev, V., Selin, V., \& Tereshchenko, E. B. (2009). Sotsial'no-Ekonomicheskie Posledstviya Ozhidaemogo İzmeneniya Klimata v Arktike. Region: Ekonomika i Sotsiologiya, 2, 125-136.

- Victor, D. G., \& Victor, N. M. (2003). Axis of Oil! Foreign Affairs, 82(2), 47-61.

- Vishinevskii, D. C., \& Demyanenko, A. N. (2010). Makroekonomicheskoi Zonirovanie kak metod strategicheskovo analiza: Dalnii Vostok Rossii. Prostranstvennaya Ekonomika, 4, 6-31.

- Vsevolodovich, V. (2012). Sever i Arktika v Novoi Paradigme Mirovogo Razvitiya: Aktual'nye Problemy. Ekonomicheskie i Sotsialnie Peremny: Fakty, Tendentsii, Prognoz, 3(21).

- Wilder, M. P. (2010). Who gets the Oil Arctic Energy Exploration in Uncertain Waters and the Need for Universal Ratification of the United Nations Convention on the Law of the Sea Houston Journal of International Law, 32(2), 505-544.

- Winchester, R. F. European Energy Security: Wrestling the Russian Bear for Caspian Natural Gas.

- Winrow, G. (2007). Geopolitics and Energy Security in the Wider Black Sea Region. Southeast European and Black Sea Studies, 7(2), 217-235. doi: 10.1080/14683850701402060

- Wood, A. (2011). Russia's Frozen Frontier: A History of Siberia and the Russian Far East 1581 - 1991 2011.pdf>. New York: Bloomsbury Academic.

- Yergin, D. (2006). Ensuring Energy Security. Foreign Affairs, 85(2).

- Young, O. R. (2011). The Future of the Arctic: cauldron of conflict or zone of peace? International Affairs, 87(1), 185-193.

- Zausaev, V. K. (2012). General Goal of the Strategy for Socioeconomic Development of the Far East and the Baikal Region up to 2025. [Article]. Problems of Economic Transition, 55(4), 45-51. 